\title{
India in the Global Chaotic Economic Order
}

\author{
Swati Watts
}

\begin{abstract}
India after going through the reforms in 1991 was eluded to feel that it is going through the transformation as if it would be globalized. India which toed the State-controlled tenets even when the pace of globalization was increasing, but it became difficult to handle the balance of payment crisis. It is at this stage the Indian economy had come out of the web and make it more open and resilient. Before it had taken the full advantage of globalization, disruptive forces pulled down the global economy and India could save itself from the downswing. It was because the market which was expanding with private and foreign investment began to fold as the flow was disrupted or foreign investment was not expected to maintain the tempo. The economy is badly stuck up because of the no effort to undertake labor reforms and also to neglect the productivity in agriculture. The mega industries were not in a position to shoulder the growth trend unless the ancillaries or subsidiaries were becoming strong. With a single structural reform in the form of GST, the MSME sector has collapsed. How far urban market absorbs the capital has its limit which has been reached and now the growth rate after falling to little over six percent will have to creep at snail pace to reach at $8 \%$ even in five years. Till then Chances of poverty to resurface are also increasing.
\end{abstract}

Keywords: Balance of payment, foreign investment, Globalization, Private investment, MSMEl.

\section{INTRODUCTION}

Uncertainty is new normal. This is the new trend which is trailing nowadays which shows nothing is certain. Indeed it is, the way global economic order stands threatened, peace agreements are overlooked and new orders are yet tentative. There is chaos all around but not a break down yet. India, one of the fastest-growing economies in the world, can feel the after-effects of this chaos. Changing the traditions is always a bold step and along with the changing world, India is ready to break the chain of traditional methods, we are ready to face the change by making some changes in the economic methods. We are living in an era where President Trump wants to take the world to relook at the global agreements. The US pullout from Iran agreement, the Paris climate change treaty and the UN human right council conveys the message loud and clear. Before that, it is important to recognize that China was the first one to play the aggressive paper, I have tried to cover the short history of the Indian economy since World War 2. This paper also analyses, the economic situations in the past which leads to global economic recessions and its effects on the Indian economy and ways in which the Indian economy can be insulated from global economic traumas.

Revised Manuscript Received on November 11, 2019.

* Correspondence Author

Dr. Swati Watts, Associate Professor, Echelon Institute of Technology, Faridabad. swatiwatts@gmail.com nationalism card in the global economic conversation. In the

\section{OBJECTIVES}

i) To identify the reasons for the global economic recession. ii) To analyze the factors which had kept the Indian economy insulated from the global economic upheavals.

Implications for research results:

The deferring of capital account convertibility had given enough protection to India while it had saved the foreign exchange reserves better than the other similar emerging economies.

\section{ABOUT THE TOPIC}

When the economic situation was devastated in the two world wars II, the same countries pledged for maintaining peace and reconstruction. The smarting up as possible with the global institutions, which were expected to lend support by the way of physical development, monetary management and trade. Therefore, the three separate institutions by the name of World Bank, International Monetary Fund and General Agreement on Tariff and Trade were created almost at the same time in 1944. At the outset, things appeared to be simple as most of the third world countries were at the primary stage of development.

However, there were few countries in the north, which were considered to be in the stage of advancement i.e. USA, Canada, Germany, France, and the USSR. As time passed Japan, Australia, and New Zealand and with the efforts of European countries to work in unison in the form of Block, these countries also considered them in the advanced stage. There was a natural lag between the advanced and developing economies. The advanced economies were expected to be technologically stronger and hence for them, human resources could be the precious assets, however, developing countries in the initial stages had very poor physical development and it is where the global development bank and regional development banks were extremely useful to improve their physical infrastructure. With time, each country began to take the benefit of trade making export as wide as possible but restricting the import depending upon its capacity to pay for it.

The trade agreements were regulated by GATT, whose important recommendation was a most forward nation. The rest was left to balance of payment situation. Since each country was expected to follow IMF fixed exchange rate i.e. each currency is pegged to the dollar and the dollar itself was pegged to gold. With the fear of depreciation and payment with gold, each country avoided lavish import. A small adjustment was allowed under the IMF. However, when import continues to exceed the export, the trade deficit could be met by IMF restricted to Standard Drawing Rights (SDR) or borrowing at a commercial rate of interest. 
There was calm till 1971 when the US economy suffered from abnormal inflation, which would have depreciated the dollar very high, but looking to the reserve of gold and situation becoming adverse, the USA decides to cut the knot with the gold and sets its currency free. Now it depends upon the countries as to which currency, these would like to peg. Rather it became the turning point, that let trade orders be not scuttled by the fixed exchange rate and trade be increased by forming customer blocs, so that countries in some region can form suitable blocs, which ensure that trade is free among the countries in the bloc, but bloc countries are free to choose any impart tariff depending upon how much import would affect their domestic conditions. With the formation of blocs, the volume of trade continued to grow. The principle of competitive advantage continued to operate in so far as the trade direction is concerned. The trade balance was still under control. But the problem begins to worsen in $8^{\text {th }}$ round of GATT, called Uruguay Round when there was a pressure by the US, that GATT is terms of growing the trade at multi trade level, as well as it is not capable of encompassing the trade in services as well as trade-related to investment. About 123 countries agreed to the transition of GATT to a multi plural organization called WTO. Although WTO convinced many countries to reduce tariff on manufactured goods as low as possible, some of them were beyond the scope of WTO and it was left to be decided by the trading partners to engage in the trade with mutual agreement. The impact of the trade of these products was not to be felt across the nations and hence through mutual agreement these are continuing.

The agriculture was such an area, in which third world countries could not come to the terms demanded by the advanced countries, whose productivity level is much higher. Countries in the third world are ranked lower to advanced countries in terms of the value of manufactured goods that are concerned and also agriculture productivity. Secondly, some countries are smaller in size, it does not matter to them if some fall or excess could be met with import or export of the agricultural commodities. Therefore, small countries did not allow agricultural commodities to come in the way of trade discussions. But still, there are many small countries, which could grow with the development of tourism and hospitality and sufficient manufacturing. Countries like South Korea and Taiwan, Singapore and Hong Kong with limited population indulge in high valued products and services. Still many countries in ASEAN, though not very poor and these were before the formation of ASEAN is doing with trade-in low valued commodities within the block. As the advanced countries, who have limited population wanted to engaged their labor force in goods and services of high value, because, it would have been inverse to engage in the low-value products given the fact that cheap labor elsewhere could be accessed. Asian Latin American, South American countries are good for accessing cheap labor. These countries have enjoyed the best advantage of investment by advanced countries.

The largest benefit has gone to the market economies of ASEAN countries and in cast Asia, China became the leading manufacturing hub. India continued with heavy consumption. Almost, it is a consumption economy and barely $30 \%$ is an investment economy. In the case of China, it is 50:50 with the control in consumption and wages, China managed to attract heavy investment in the manufacturing sector. First the abundance of labor in the beginning and secondly with training and controlled wages, China succeeded in creating a bastion of manufacturing and no country could dare to supply the goods at dam cheaper rate as China could and therefore, it continued to make current account surplus which made its foreign exchange reserve still stronger.

While the state of Europe not to be changed and it's giving up manufacturing to Japan and China export increased terribly. While India practically found free to engage in the liberalized environment in 1991, very insignificant was done to improve the export. No doubt, because of its English speaking population, the service sector foreign earning was an advantage over. Secondly, due to its big market size, the flow of foreign investment continued for a long time, with which the current account deficit remained manageable even though the impact was mostly high in the days of high global growth.

As the years passed and economics in the North found themselves unstack in the hurdle, the CAD was adjusted with sovereign borrowing by the US. Whereas, since the formation of unified currency Euro in Euro block the old economics found themselves wrangled in fiscal deficit and hence repeated public borrowing continue over the years. The excessive sovereign wealth in the Gulf, China and ASEAN made their way to us, which was running on dissaving. Therefore at any point in time, its debt level was not break-even but excessive speculative tendency generally thrive on the debt, because in these situations interest rate goes down and stock prices go up without knowing the underlined reality. There was a huge market crash in 2008 in the US and since banks in Europe and the US are intimate with other heavy cash losses took peace in the market crash. Once taxpayers' money was burnt, the Government has to save upon the depositors and therefore Government was expected to infuse capital. Both things happened simultaneously when the stock market crash hurt the business and related revenue, the high fiscal deficit would have not allowed the public borrowing and hence quantitative easing become necessary.

Low-interest rates and flush of liquidity for some time resuscitated the economy to some extent. But by the time, developing was expected to be followed and hence control of current account deficit was necessary. Looking at the unemployment situation and current account deficit has been imposing the unusual tariff on an import from each country. To what extent, it would work, time alone will tell. But for time being, China managed to depreciate the currency to clear the normal export and switching gears towards the consumption to maintain the product growth level.

The story of Europe is different. UK was not at ease anytime in joining the EU. But the recession of 2008, which has shaken the UK economy more than expected, it sought Brexit means that economic integration without borders with the EU is not to be sought after henceforth. Since the referendum for Brexit could not be altered even after two Prime Minister had to lose their job, anytime, it has to be there. It means already crumbling EU, will suffer a big jolt. The fall in the euro bloc economies could not 
be corrected by fiscal transfer by Germany alone, but to some extent, it was done by ECB, which reduced interest rates as well as push liquidity.

The printed money in circulation is so high that bond yield is negative, which indicates that business can't absorb the money and if the Government is absorbing it indicates that recovery is far delayed in the future. Bond yield across the globe has fallen excessively, because of a business slowdown, come out of productivity, rise in wages and good employment. Except for economics, the situation is grim. But small economics, which began to grow much after the shifted away from China.

India missed the train in 1991 and even now it is not prepared to grab this opportunity. Since the largest economy in Europe i.e. Germany is facing a recession because of the collapse of other economies in Europe. How things would move forward is uncertain. The challenge has been thrown to the US, to navigate the global economy in a positive direction, but for the time being uncertainty that growth trajectory would reverse soon is acute. The lesson, which is learned from global disorder is that as the economics tend to gain the orientation of market economics, they should have to have a strong financial sector, reducing the current account deficit as far as possible and also work hard on human development. Whereas China has rightly placed itself in the wave of globalization and India continued to take explicit benefits of it, but the US could not take the cognizance that its import most of the consumer goods is excessively increasing than the exports of patented and intellectual products, which at the time of crisis was badly exposed. When it was giving up manufacturing, it did not see that the research and innovation-based products would not be sold so easily particularly in China which cleverly managed the high growth and India continued to evade the rules of WTO. IMF has given up to flexible and maneuvered exchange rates, WTO could not thrust upon the rules of trade, have thrown back the countries apart, but world bank is still doing the noble work as before. The currency disorder in 1971 and the trade order in 1995 could not find all the countries on one platform. China is uniting the countries in RCEP and other small groups are in the process of creating regional currency blocs and development institutions. But the US snapping ties with each country indicates that there is something different which it is planning. Since all the roads emerge from the US, it is difficult that some different pathways can lead to growth which subjugates the US.

Since manufacturing was expected to be cost-competitive as well as diversified, China alone could take the benefit, which has succeeded in accumulating huge reserves. But the way, it is evading the norms of WTO came to light on only 2008 and by that time drama was over. Since global slowdown is massive and it is likely to be stretched still over a longer period and along with demographic concerns in Europe and North are real, if all revival is there, surely, it would not be in the same manner as it was earlier. Secondly, automation and artificial intelligence if used can cut down the cost drastically, whether the US would like to take back the advantage of manufacturing depends upon several other factors. Financial imbalance, which had taken place in all which is related to demand and demand was expected to formation of WTO are taking advantage of produce, which is

these years is taking to correct and till it is corrected. Further growth may not be visible. Slow ever most of the economies have already compromised with their domestic growth with a low level of export. The huge swing in the exchange rate has come to stop. It is a bare minimum growth, which has been going on and things are standstill.

\section{Appendix}

Top 8 countries with the largest deficit

\begin{tabular}{|l|l|l|}
\hline Country & Million US \$ & Billion US \$ \\
\hline USA & $-466,200$ & -466 \\
\hline UK & $-106,700$ & -107 \\
\hline INDIA & $-57,200$ & -57 \\
\hline CANADA & $-49,260$ & -49 \\
\hline TURKEY & $-47,100$ & -47 \\
\hline FRANCE & $-36,770$ & -38 \\
\hline AUSTRALIA & $-32,270$ & -32 \\
\hline ARGENTINA & $-30,790$ & -31 \\
\hline
\end{tabular}

GDP (Nominal) (in billions US \$)

\begin{tabular}{|c|c|}
\hline Country & GDP \\
\hline USA & 21482 \\
\hline CHINA & 14172 \\
\hline JAPAN & 5220 \\
\hline GERMANY & 4117 \\
\hline INDIA & 2957 \\
\hline FRANCE & 2844 \\
\hline UK & 2809 \\
\hline ITALY & 2112 \\
\hline
\end{tabular}

Top 10 countries in terms of exports (in billions US \$)

\begin{tabular}{|c|c|}
\hline Country & Exports \\
\hline CHINA & 1990 \\
\hline US & 1456 \\
\hline GERMANY & 1322 \\
\hline SOUTH KOREA & 512 \\
\hline FRANCE & 507 \\
\hline HONG KONG & 502 \\
\hline NETHERLAND & 495 \\
\hline ITALY & 454 \\
\hline UK & 407 \\
\hline CANADA & 394 \\
\hline
\end{tabular}

Countries with the largest foreign exchange reserve (in billion US \$)

\begin{tabular}{|c|c|}
\hline Country & Foreign reserve \\
\hline CHINA & 3210 \\
\hline JAPAN & 1259 \\
\hline SWITZERLAND & 804 \\
\hline SAUDI ARABIA & 501 \\
\hline RUSSIA & 460 \\
\hline TAIWAN & 459 \\
\hline HONG KONG & 425 \\
\hline INDIA & 403 \\
\hline SOUTH KOREA & 402 \\
\hline BRAZIL & 379 \\
\hline
\end{tabular}


The above table indicates that India is losing the momentum of growth since the time the global recession had started in2008. Before 2008, it was disinvesting as well as getting significant FDI because of the strong market. But after 2008, the demand across the countries has affected the downside. The supply side is also shrinking. Even though inflation is nominal as low as it could be but the growth is also sliding down. The reason is that the private sector is not very optimistic in this scenario when the income of the people is falling. In this scenario, the investment is also sliding down. The basic reason for this slide is that when the global economic conditions were on the rise, it continued to absorb the foreign capital but at one point in time it got saturated due to income gaining the peak. Therefore to expand the market the economic potential was expected to grow further and it was possible with the reforms in the factor market. China had projected long term growth targets and they had gone up to the level of $12 \%$ and their courage to achieve Yuan as the reserve currency is also appreciated the world over. Each government in India comes with different paradigm and put the economy in the direction which could better serve the social sector without putting them to the task of gaining strength with human efforts. The educational standard of India is third rated. Poor have no access to medical facilities. Even farmers committed suicide. Farmer's community is at the bottom of the pyramid. The earlier rupee was the devaluing because the hot flow was turning back but now the hot flow is going back due to growth sliding down. It is not called globalization. It is one side that when you opened the markets FDI has come to capture the market of the country but India has created almost nothing to access other markets by carefully designing the exports. Since exports have not been targeted so is the import to be used in the exports is completely missing in the Indian context. Now many countries are in the crisis and many of them are still facing the fear of recession despite that their currencies were convertible. India and China could have led the Asia-Pacific if in true sense it had bothered itself to globalize with two-way benefits.

\section{CONCLUSION}

It has been concluded that since the formation of WTO, the largest country to be benefitted i.e. China had taken the escape route to follow the rules of the game and hence spelled trouble to the US. While all the emerging economies rising on the wave of globalization had suffered the brunt of the crisis, these are struggling with the odds in the monetary and fiscal regimes. Developed countries are back to protectionism and the trade war is at the zenith where no one is likely to be benefitted. The countries are once again strengthening the Free Trade Agreements except for the US and Europe, which are still deep into the crisis of growth, employment and consumption. Both the IMF and WTO appear to have given effort on the terms of trade and currency stabilization. The governing organizations may find it difficult to enforce the laws because first the exchange rates were distorted and now trade also. A new system of governance shall be needed when there is calm among the top economies. But meanwhile China is taking BRI initiative and RCEP is working in full strength and is taking along 16 countries. Till the EU gains the lost glory before the euro, the western countries appear to be in shaky conditions. One should treat the Great Depression of 1930 less severe than the recession of 2008 because it is taking a too long time to recover.

\section{REFERENCES:}

1. Baru, Sanjaya 2016, 1991: How PV Narashima Rao Made History, Aleph, New Delhi.

2. Bhagavan, Manu 2013, India and the Quest for One World: The Peacemakers, Palgrave MacMillan, New Delhi.

3. Dash, Kishore C. 2012, 'The Dynamics of South Asian Regionalism,' in Mark Beeson and Richard Stubbs (eds.) Routledge Handbook of Asian Regionalism, Routledge, London, pp. 406-419.

4. Ikenberry, G. John 2005, 'Power and Liberal Order: America's Post-war World Order in Transition,' International Journal of the Asia-Pacific, Vol. 5, pp. 133-152.

5. Jaishankar, S. (2015). 'India, the United States, and China.' IISS Fullerton Lecture, 20 July.

6. Kliengibiel, Stephen, 2016, 'Global Problem-Solving Approaches: The Crucial Rose of China and the Group of Rising Powers,' Rising Powers Quarterly, Vol. 1, No. 1, pp. 33-41.

7. Krauss, Keith 2007, 'Disarmament,' in Thomas G. Weiss and Sam Daws (eds.), The Oxford Handbook of the United Nations, Oxford University Press, New York, pp. 287-299.

8. Mearsheimer, John J. 1994/95, 'The False Promise of International Institutions,' International Security, Vol. 19, No. 3, pp. 5-49.

9. Mohan, C. Raja, 2010, 'Rising India: Partner in Shaping the Global Commons,' The Washington Quarterly, Vol. 33, No. 3, pp. 133-148.

10. Mukherji, Rahul 2014, 'India and Global Economic Governance: From Structural Conflict to Embedded Liberalism,' International Studies Quarterly, Vol. 16, No. 4, pp. 460-466.

11. Goldberg, Jeffrey 2016, 'World Chaos and World Order: Conversations with Henry Kissinger,' 10 November, The Atlantic, https://www.theatlantic.com/international/archive/2016/11/kissinger-order-an d-chaos/506876/.

12. Kahler, Miles, 2013, 'Rising Powers and Global Governance: negotiating a change in a resilient status quo,' International Affairs, Vol. 89, No. 3, pp. 711-729.

13. Kagan, Robert 2017, 'The twilight of the liberal world order,' 24 January, Brookings Institution,

https://www.brookings.edu/research/the-twilight-of-the-liberal-world-order/.

14. Roach, Stephen S. 2016, 'The Globalisation Disconnect,' 25 July, Project Syndicate,

https://www.project-syndicate.org/commentary/find-solutions-for-free-trade-ba cklash-by-stephen-s-roach-2016-07?barrier=accessreg.

15. Ruggie, John Gerard, 2004, 'American Exceptionalism, Exemptionalism, and Global Governance,' in Michael Ignatieff (ed.) American Exceptionalism and Human Rights, Princeton University Press, Princeton, NJ, pp. 304-338.

16. Posen, Barry R. 2009, 'Emerging Multipolarity: Why should we care?', Current History, Vol. 108, No. 721, pp. 347-352.

17. Pant, Harsh V. 2016. Indian Foreign Policy: An Overview. Manchester: Manchester University Press.

18. Pant, Harsh V. 2017. "The dying embers of the old order in Asia."

Livemint, 30 March.

http://www.livemint.com/Opinion/OpJ5mjSVw08k4qeE0EI1rN/The-dying-e mbers-of-the-old-order-in-Asia.html

19. Paris, Roland 2015, 'Global Governance and Power Politics: Back to Basics,' Ethics and International Affairs, Vol. 29, No. 4, https://www.ethicsandinternationalaffairs.org/2015/global-governance-powerpolitics-back-basics/.

20. Press Trust of India, 2016, "India decries "undemocratic" Global Governance,' 26 April, The Economic Times, http://economictimes.indiatimes.com/news/politics-and-nation/india-decries-u ndemocratic-global-governance/articleshow/51986885.cms.

21. Sidhu, WPS, Mehta, Pratap Bhanu, and Jones Bruce, 2013, 'A Hesitant Rule Shaper' in (eds.) Shaping the Emerging World: India and the Multilateral Order, Brookings Institution Press, Washington DC, pp. 1-19.

22. Xuetong, Yan 2011, 'From a Unipolar to a Bipolar World System: The Future of the Global Power Dynamic,' 30 December, The Global Times. http://carnegietsinghua.org/2011/12/30/from-unipolar-to-bipolar-superpowersystem-future-of-global-power-dynamic-pub-47688.

23. Blyth, Mark 2007, 'One Ring to Bind them All: American Power and Neoliberal Capitalism," in Sven Steinmo and Jeff Kopstein (eds.) Growing Apart: America and Europe in the Twenty-First Century (Cambridge: Cambridge University Press 2007) pp. 109-136. 